\title{
An Investigation of House Designs in Lahore: Transformation of Residential Architecture from traditional to modern
}

\author{
Sana Malik ${ }^{1,2^{*}}, \mathrm{Ku}$ Azhar Ku Hassan ${ }^{3}$ \\ ${ }^{1}$ PhD Candidate, School of Housing, Building \& Planning, Universiti Sains Malaysia, 11800 \\ Penang, Malaysia \\ ${ }^{2}$ Assistant Professor (Study leave), School of Architecture \& Planning, University of \\ Management \& Technology, Lahore, Pakistan \\ ${ }^{3}$ Associate Professor, School of Housing, Building \& Planning, Universiti Sains Malaysia, \\ 11800, Penang, Malaysia \\ *sana.malik@umt.edu.pk
}

Received : 29 April $2018 \quad$ Final Version Received: 19 March 2019

\begin{abstract}
Many historic cities display the expression of individual and cultural identity as a common phenomenon in house designs; this paper inspects it in context of Lahore city. Study is focused on architectural transformation of house designs based on lifestyles of different time periods in Lahore. The objective is to highlight the key modifications in designing of houses over time period of half century. It is believed that home is the most endearing structure to be built given the poignant connection of dwellers to their living spaces. In Lahore, houses show diverse architectural profile as a result of socio-economic changes and global influences; these demand to investigate the present prototype of traditional versus modern house design in Lahore. A case study of traditional as well as modern house was conducted using field inspection and typological analysis. Findings of such design focused research provide helpful insights for practitioners and academicians of contemporary architecture in Lahore and other likewise cities, about major spatial and design alterations in order to achieve a balanced approach in residential architecture.
\end{abstract}

Keywords: Lahore, Residential Architecture, Transformation, Traditional Houses, Modern Houses.

\section{INTRODUCTION}

Pakistan has rich historical and cultural texture of architecture. Housing design incorporates social, economic, personal and intellectual concentrations beyond what is seen as built construction. This association with house design prompts stakeholders to apply modern as well as traditional dynamics resulting in complicated schema of house design eventually. The very existence of an individual cannot be thought without a house. In popular imagination, a house is a building which has kitchen, a bathroom, bedroom, and a lounge built to provide shelter and protection (Chauhan et al., 2009). Also, it reflects the social norms and aesthetic manners of a family from two aspects: from interior, through the adjustments of spaces and from exterior, through architectural features of the facade. The practice of building modern houses has become excessive in Lahore, the second largest city of Pakistan.

Within its context, a variety of architectural styles is observed in the planning and facades design of house. This assorted nature of designs has created confusion in establishing the vernacular architecture of houses. A common inspection reveals that some homeowners are can go for unique designs for decorating overhead water tanks (Fig. 1). Traditional designs are disappearing from the face of residential patterns in Lahore and are being replaced by modern designs. There is dire need to scrutinize the adaptation of traditional house design versus modern house design. Due to lack of such research, this study aims to develop insight into the transformation of house design in Lahore from traditional to modern. Presently, the 
trends in housing design are inclined more towards western pattern of architecture and planning, irrespective of understanding the regional demand of residential designing. Therefore, it is important to recall the constructed examples of houses that survived the natural and environmental tests over the years. A concurrent study combining the case of modern house design with traditional one, would help document the degree of transformation in residential architecture in the city.

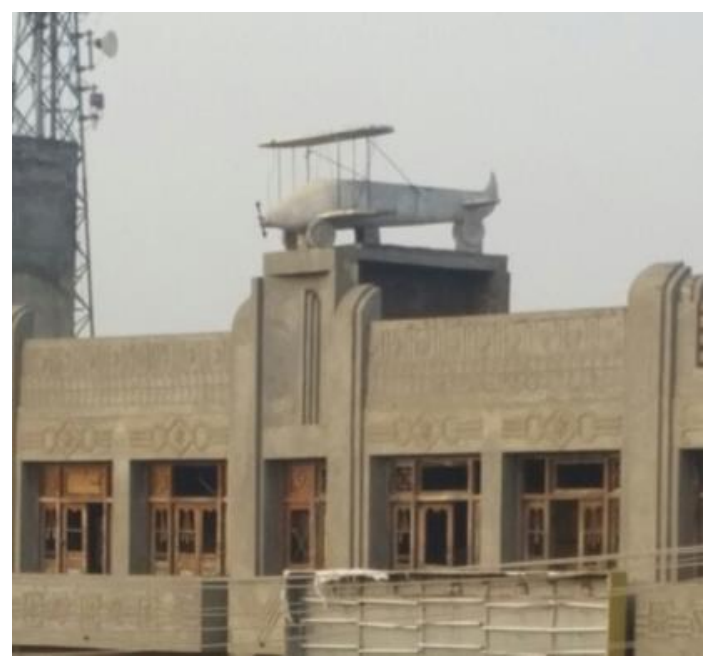

Fig. 1: Design of Overhead Water Tank in Lahore, Source: Author.

\section{RESIDENTIAL ARCHITECTURE OF LAHORE}

Lahore is second largest city of Pakistan and holds great significance due to its rich cultural, political and architectural history. Architecture of city has undergone remarkable transformations due to three major chronological periods, i.e., Mughal, British Colonial, and PostIndependence. During the pre-colonial times, the British had looked upon Lahore as a very fragmented space, divided into different institutional, public, professional and communal categories (Shafique \& Shahid, 2016). Like all ancient cities, Lahore also has two faces, the old and the new; the old city is the reminiscent of the past glory of Lahore and the new city gives a modern look (Mubin, Gilani \& Hasan, 2013).Traditional house design in Lahore is a prominent feature of the local architectural style due to its prolonged association with historical context. Housing units are further divided into different categories depending on income and family size of the home owners. Traditional houses consists of attached and detached homes. A short account of these categories is given below.

\subsection{ATTACHED TRADITIONAL HOUSES}

The city hosts various historical monuments, buildings and gardens along with a walled city during the Mughal era (1524-1752) and British colonial rule (Rana \& Bhatti, 2018). The Walled City also known as called Androon Shehar in native language, was the prime social and economic center of the city during that time. The houses had strong architectural features like 'jharokas' (balconies) and detailed ornamental features. These attached houses were packed units with less covered area and small room sizes respectively. The approach for attached houses was considered to be sustainable in terms of climatic conditions and strong community development. Batool (2014) specified that traditional buildings maintained thermal comfort though architectural elements like jalis (screens), verandas, jharokas (balconies), fountains, plants, chajjas (overhangs), courtyards, and basements. Shared walls of houses and narrow streets tend to encourage daily neighborhood interaction creating a sense of security and safety while people used to sit at doors and outside. Nevile (2006) referred to this culture of joint family as the accepted norm, and true, to the socialist ideal of sharing all things together, people enjoyed the pleasures of the housetop in equal measure. The houses, though lofty and to all appearances well built from the outside, yet cramped inside and illventilated. Attached houses of the walled city started to lose their popularity with end of Mughal Period and the invasion of British rulers, and then Lahore started to develop in another direction of town planning.

\subsection{DETACHED TRADITIONAL HOUSES}

The model of detachable houses promoted the idea of open dwelling spaces surrounded by open passages and gardens in front of the house. To live in such a space where a separate identity of one's house could be celebrated easily was a sign of prestige. Before the independence of Pakistan, the Indian residents, who arrived to live in Model Town, developed houses on their own. For instance, at that time houses were built as singlestory British bungalows. Bhardwaj and Garg (2016) described that the bungalow typically consisted of a low, one storey, spacious building, internally divided into separate living, dining andbedrooms, the latter with attached rooms for bathing. The British style incorporates many of the features of the 'grand' classical style, adapted to become normal in shop houses; including iron grilles, dormers, balconies, pediments, pilasters, keystones and arches (Ovais, 2016). Courtyard 
houses are also types of detached houses in Lahore context. Noble (1987) described centered courtyards in the square and rectangular houses that were seem invariably to be surrounded by a veranda or by a shaded space, with some houses partially extending outward as far as the outer walls. This historical house type came into use to address the harsh weather in the region. Not only do courtyard houses portray a form of architectural style in residential building, but they also depict a way of life. The rooms located around the courtyard ensured strong family bonding and interaction. The central open space is the dominant feature of the entire house at every celebratory function because of its central orientation. Lodi et al. (2013) further analyzed that the height of walls varies from 9-12 feet in height for warmer climatic zones with ventilation at the top, and lower for colder zones to keep the interior warm.

\subsection{MODERN HOUSES}

Recent studies have established that the development and spread of gated neighborhoods has become a part of new housing scheme. Lahore has approximately 40 gated neighborhoods which are inhabited, and few more are currently under construction. (Rahmaan \& Anis, 2009). Vandal (2011) described that the housing typology launched through government houses schemes in Lahore such as Officer's houses in Military Cantonment Area, Officers houses for Railways, and others changed the concept of living dramatically from attached to detached house type. The inverted two-story bungalow (colonial prototype) proclaims the socially accepted model of living in the current scenario countrywide. This paradigm has contributed in creating social inequity among the inhabitants of Lahore city.

The current house model lacks the concerns of common man and do not fit in a neighborhood setting of Lahore. The modernity and contemporary trends in living style are changing the old customs of practice in building and construction. This has resulted in transforming the patterns of spatial planning and architectural forms.

The design shift proved an economical alternative for constructing several houses with a low design profile in comparison to traditional houses with exaggerated ornamentation. Qureshi (2015) asserted that, at present, though the construction materials, layout and family setup of houses are similar to each other, a variety of front facades are visible throughout the city.
However, the low percentage of houses reflects a balanced approach of house design as a combination of traditional and modern patterns, in lieu of which Qadeer (1983) reported that house designs combine modern and traditional features in a harmonious blend. Modern design features include rectangular plans with plain concrete slab, squarish appearances with nominal decoration, low ceiling heights, large windows, and controlled circulation by compacting the space planning. Whereas Burgess (2005) focused on the fact that community houses, group houses, or apartment houses are more and more required by our modern nomadic ways of life. Hence, in near future, this could signal reverting back to the concept of attached houses.

\subsection{FACTORS INFLUENCING RESIDENTIAL ARCHITECTURE OF LAHORE}

Various factors influence residential spaces. However, in recent times, the housing tendencies are observed to be more subjective to globalization, regulatory frameworks and other cultural aspects. Following factors are derived from personal observation on behalf of the current market trends.

\subsubsection{GLOBALIZATION}

Technological advancements in economic and social processes formulate the most profound factor in order to alter the architectural trends of a region. International brands of food, fashion, building construction industry, electronics, and furniture etc., hold extraordinary presence in the eyes of the general public when they hit the local markets. All of these brands demand their space in an architectural setting and play an important role in manipulating the daily living style.

\subsubsection{EXPOSURE}

Exposure to international styles of architecture plays an important role in shaping up the residential design. Internet and Telecommunication industry has made the majority of common people familiar with various western trends of home space design. In addition to this, travelling leaves an exclusive impression in minds of people. This retained experience changes the perception in a creative manner. Such an exercise prompts the involved stakeholders to be more imaginative with their house designing ideas and abandon the traditional format of house design. 


\subsubsection{SOCIAL TENDENCY}

The people living in Lahore have a great tendency to inspire from one another about house design and construction. This social habit of inclination among Lahoris (people of Lahore) plays decisive role, sometimes when they start planning to construct their dream home. Such attribute sometimes even result in executing the whole layout and design of house as carbon copy of another house on the same street or as replica of some family member's house.

\subsubsection{CUSTOMIZATION}

There is a high level of involvement in house design from the client as compared to an architect. Such a practice is greatly affecting the image of residential architecture of Lahore. Eventually, customized design proposal will be dominated by a client rather than an architect's draft. It is now common for a client to format the ingredients of house design such as space requirement, color combinations, façade style, bedrooms size and the kitchen detailing. In some ways, this exercise eradicates the pure role to be played by architect in the design process.

\subsubsection{BUILDING REGULATIONS}

Aspect of Building regulations is one of the factors behind, affecting the house designs in Lahore. Such regulations feature the rules and guidelines from concerned development authority. Thorough consideration of these regulations is required for official approval of house construction. Floor area ratios and setbacks from the periphery of plot, alter the residential outcome under such obligations. Similar is the case of regulatory framework being implemented in study area of Lahore (Fig 2). Due to this restriction, many aspects of sustainable design and deep beauty fall short. Consequently, the integration of sun and wind direction becomes missing factor in the design scheme of a house.

Fig. 2: Building Regulations for residential plots in Lahore, Source: (Lahore Development Authority, 2017

\begin{tabular}{|l|c|c|c|c|c|}
\hline \multicolumn{1}{|c|}{ Plot Size/Zone } & $\begin{array}{c}\text { Max No. of } \\
\text { Storey } \\
\text { (excluding } \\
\text { basement) }\end{array}$ & $\begin{array}{c}\text { Max Ground } \\
\text { Coverage }\end{array}$ & $\begin{array}{c}\text { Max } \\
\text { Height }\end{array}$ & Max FAR & $\begin{array}{c}\text { Minimum } \\
\text { Parking } \\
\text { Provision }\end{array}$ \\
\hline Less than 5-Marla & 3 & $80 \%$ & $38 \mathrm{ft}$ & $1: 2.4$ & $\begin{array}{c}\text { Not } \\
\text { Mandatory }\end{array}$ \\
\hline $\begin{array}{l}5 \text { Marla \& above } \\
\text { but less than 10 } \\
\text { Marla }\end{array}$ & 3 & $75 \%$ & $38 \mathrm{ft}$ & $1: 2.3$ & 1 Car Space \\
\hline $\begin{array}{l}\text { 10 Marla \& Above } \\
\text { but less than 1 } \\
\text { Kanal }\end{array}$ & 4 & $70 \%$ & $45 \mathrm{ft}$ & $1: 2.8$ & $\begin{array}{c}1 \text { Car Space } \\
\text { Per Storey }\end{array}$ \\
\hline 1 Kanal to 30 Marla & 4 & $65 \%$ & $45 \mathrm{ft}$ & $1: 2.6$ & $\begin{array}{c}1 \text { Car Space } \\
\text { Per Storey }\end{array}$ \\
\hline $\begin{array}{l}\text { Above 30 Marlas } \\
\text { but less than 2- } \\
\text { kanals }\end{array}$ & 4 & $60 \%$ & $45 \mathrm{ft}$ & $1: 2.4$ & $\begin{array}{c}2 \text { Car Space } \\
\text { Per Storey }\end{array}$ \\
\hline 2-kanals \& above & 4 & $55 \%$ & $45 \mathrm{ft}$ & $1: 2.2$ & $\begin{array}{c}2 \text { Car Space } \\
\text { Per Storey }\end{array}$ \\
\hline
\end{tabular}

\section{RESEARCH METHOD}

Current research is a qualitative study inspecting the degree of transformation in house designs of Lahore from traditional to modern. The case study was carried out through field work in the form of pictures and architectural drawings. Typological analysis was applied to carefully investigate the spatial layouts and planning of selected houses. To effectively study the transformation in house design, individual cases of traditional and modern house designs in Lahore city were selected. Typological analysis included ratios of covered and uncovered area, 
spatial planning and arrangement of rooms inside the house, circulation spaces, and location of staircase, etc. Further elaboration of design aspects includes the facade design and ornamental characteristics on house elevation. Nonetheless, Lahore is home to a huge number of traditional and modern houses yet to be discovered. Since the proposed study is quite specific in examining transformation of house design, a single model of traditional and modern houses was preferred. However, concern issues of local house designs can be generalized through this limited study to illustrate a necessary picture of design transformation in houses of Lahore. The analysis of the qualified transformation is documented through a comparative typological analysis of traditional and modern houses. The detached house type (Model Town, Lahore) was selected as the case study for traditional type, while house (Defense
Housing Authority-DHA, Lahore) was chosen for the modern one. It was make sure that selected houses should match with housing society location. Both Model Town and DHA are considered to be well-known for their historical and modern context in Lahore. (traditional) and current decade (modern) through spatial layout inspection and façade setting.

\section{TYPOLOGICAL ANALYSIS: RESULTS AND DISCUSSIONS}

The different features of house designs for traditional and modern categories are discussed in detail. However, a brief summary of the typological Analysis as given in the following table will help in understanding the key points of transformation in the designing of dwelling spaces in Lahore.

Table1: A summary of documented Architectural transformations in traditional and modern house designs of Lahore, Pakistan. Source:

\begin{tabular}{|c|c|c|}
\hline $\begin{array}{l}\text { Architectural and } \\
\text { Spatial Patterns }\end{array}$ & Traditional House & Modern House \\
\hline Location & Model Town, Lahore & Defence Housing Authority (DHA), Lahore \\
\hline Plot Size & 122 feet $x 153$ feet & 50 feet $\times 90$ feet \\
\hline By Laws Applied & No strict By laws & $\begin{array}{l}\text { Strict by laws applied ( } 15 \text { feet from front, } \\
5 \text { feet from all three sides of plot) }\end{array}$ \\
\hline $\begin{array}{l}\text { Ratio of Covered } \\
\text { and Open Areas }\end{array}$ & $\begin{array}{l}\text { Dominance of Open Space, encouraged the } \\
\text { assortment of indoor space with outdoor } \\
\text { lawn }\end{array}$ & More Covered Area, Less Open Spaces \\
\hline Spatial Planning & $\begin{array}{l}\text { Podium, Side lawns, Back Central } \\
\text { courtyard. Single-Story Structure }\end{array}$ & $\begin{array}{l}\text { Entrance lobby, formal spaces (Drawing \& } \\
\text { dinning) followed by informal spaces (living } \\
\text { \& bedrooms) }\end{array}$ \\
\hline Quality of Walls & load bearing walls of 13.5 inches thickness & Load bearing walls of 9 inches thickness \\
\hline Staircase Design & Outdoor location, simple paint finish & $\begin{array}{l}\text { Indoor Location, Marble Finish with a } \\
\text { stylish handrail made of polished wood and } \\
\text { glass }\end{array}$ \\
\hline $\begin{array}{l}\text { Lightening \& } \\
\text { Ventilation }\end{array}$ & $\begin{array}{l}\text { Natural lighting and ventilation through the } \\
\text { inner courtyard. High ceiling heights with } \\
\text { ventilator helps in dispersing warm }\end{array}$ & $\begin{array}{l}\text { Private lifestyle, Mechanical Lightening \& } \\
\text { Ventilation (Air conditioning). Less } \\
\text { dependence on natural sources of lightening. }\end{array}$ \\
\hline $\begin{array}{l}\text { Doors and } \\
\text { Windows }\end{array}$ & $\begin{array}{l}\text { Double set of frames in windows \& doors, } \\
\text { enables dual opening scheme towards both } \\
\text { indoor and outdoor, along with light } \\
\text { decoration. }\end{array}$ & $\begin{array}{l}\text { Sliding windows are more in fashion. } \\
\text { Modern door designs incorporates latest } \\
\text { materials. }\end{array}$ \\
\hline Façade Design & $\begin{array}{l}\text { Controlled ornamentation and detailing, } \\
\text { Neglected maintenance of the exterior } \\
\text { façade, Paint finish material. Humble } \\
\text { depiction of Doric columns. }\end{array}$ & $\begin{array}{l}\text { Play of volumes through projection and } \\
\text { depression of straight and diagonal forms. } \\
\text { application of combination of latest } \\
\text { contemporary exterior materials }\end{array}$ \\
\hline $\begin{array}{l}\text { Miscellaneous } \\
\text { features }\end{array}$ & $\begin{array}{l}\text { Angeethi (Fireplace), Plaster decorative } \\
\text { features on the ceiling at fan point }\end{array}$ & $\begin{array}{l}\text { Wall Treatments (Abstract patterns } \\
\text { embedded with modern industrial finishes } \\
\text { backed with diffused artificial lighting), } \\
\text { modern fireplace with sleek finish of black } \\
\text { granite }\end{array}$ \\
\hline
\end{tabular}




\subsection{COVERED AREA AND OPEN AREA RATIO}

The covered area and open area ratio is very important with reference to spatial planning of a house. The plot size used to be bigger for traditional houses and was not subject to severe regulations of the housing authority. This encouraged the assortment of indoor space with outdoor lawn. The plot sizes were bigger in Model Town: the plot size of the selected traditional house is 122 feet $\times 153$ feet. The shaded area shows the spacious front and side lawn with a setback of 35 feet from the boundary wall (upper, Fig. 3). Also, the courtyard at the back of house showcases an open space with a side entrance from the lawn. Hence, the open area is dominant over the covered area giving a spacious look to the house (lower, Fig. 3 ).
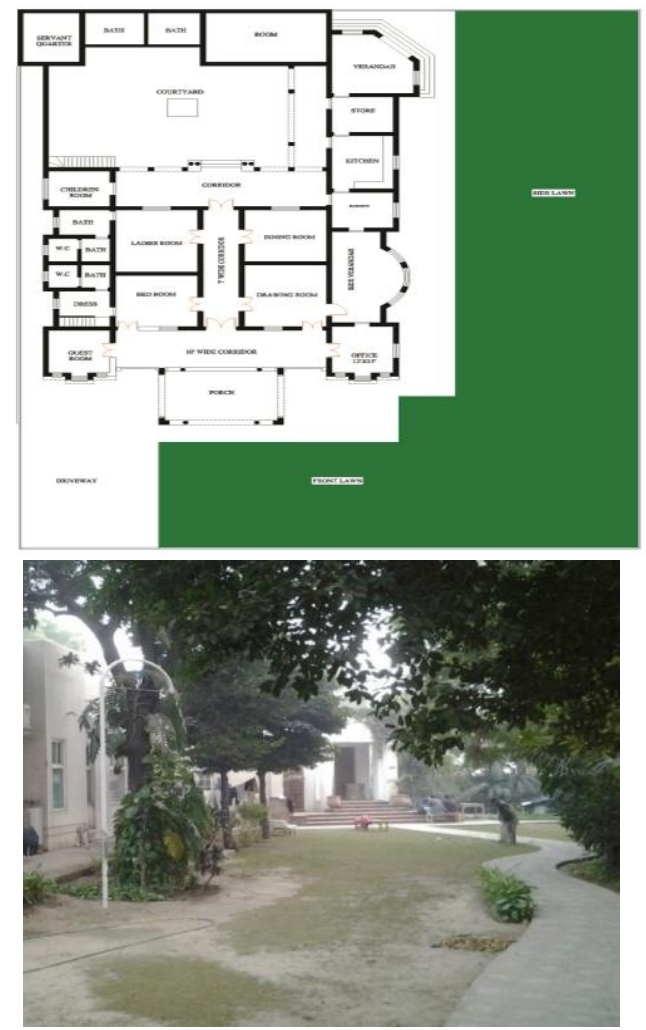

Fig. 3. Site plan of Traditional House (upper)and View Of Side Lawn (lower), Source: Author

For modern houses, dwelling is being constructed according to building regulations of respective housing authority. In case of modern house, the concerned authority was Defense Housing Authority (DHA) providing regulatory framework for a plot of 4500 square feet ( 50 feet x 90 feet) with a setback of 5 feet offset from all three sides and 15 feet from the front side of the plot facing the road. Such a customary aspect of modern housing has restricted the engagement of open areas with indoor spaces (Fig. 4).

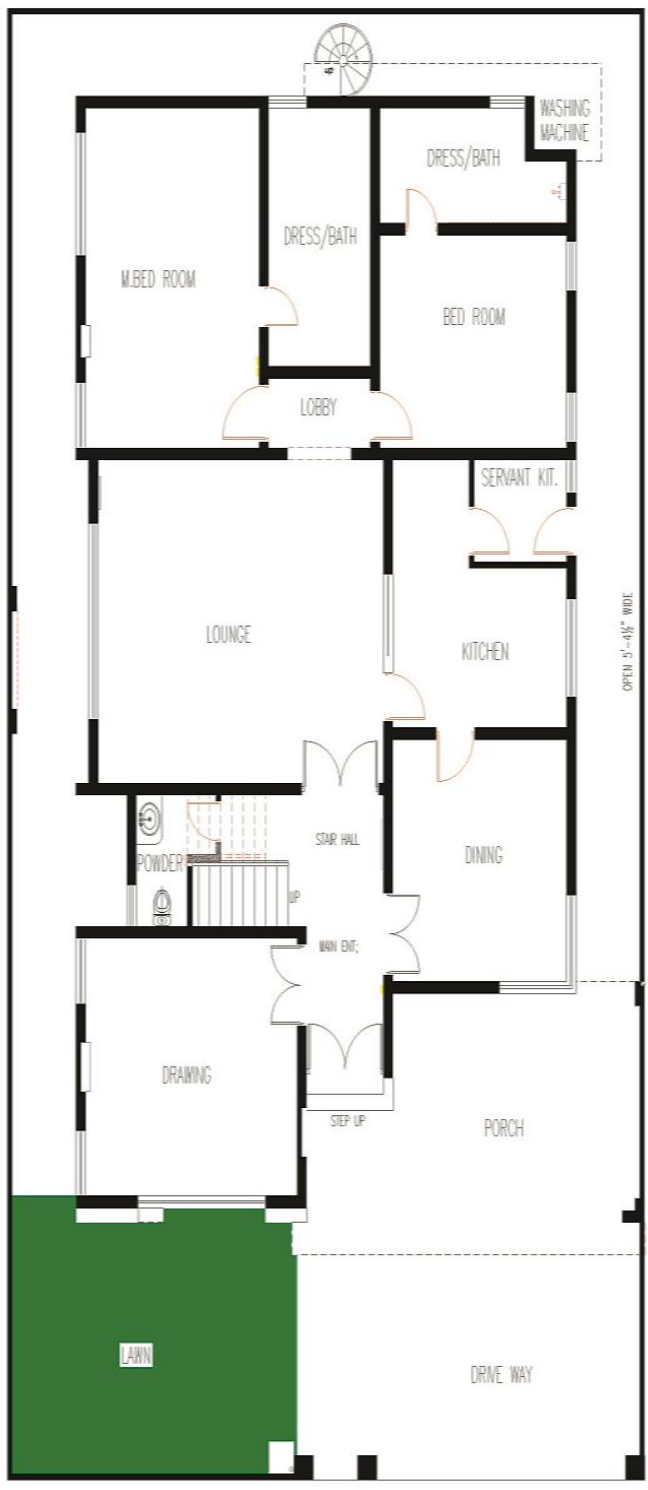

Fig. 4. Site plan of Modern house, Source: Author

\subsection{SPATIAL PLANNING}

The traditional house is attributed with a podium followed by an entrance lobby for welcoming and receiving guests in a casual style. This depicts a true sign of a detached house concept developed for the elite class of Model Town. The rooms were placed parallel along the central corridor. This corridor opened onto the courtyard through the intermediate space of verandah (covered passageway). The courtyard is placed as the central point of covered area with rooms on three sides and a staircase on fourth side thatleads to the roof. Servant quarters were 
observed at the back corner within the courtyard (Fig. 5.A).

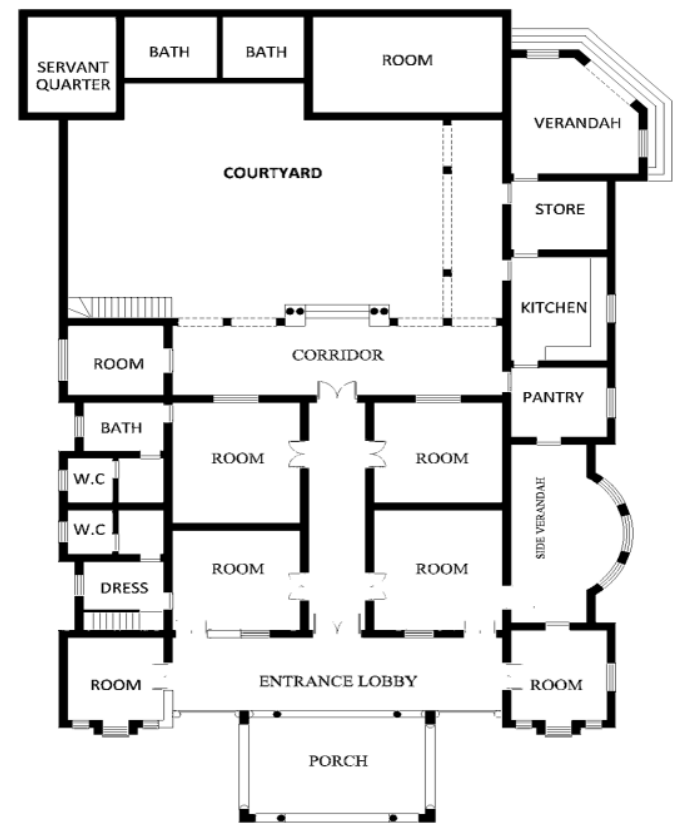

Fig.5A: Traditional House Plan

These features of spatial planning of detached traditional houses of Model Town were best described by Sengupta (2007): 'the front of the house followed the British pattern of flowerbed bordered garden, verandah, drawing \& dining rooms, the back had the local features of courtyard, kitchen, multipurpose rooms for sitting and sleeping in. Spaces inside the modern house were placed in closed manner, unlike the traditional house. This portrays inclination towards privacy and security in daily life. The direct entry without any transitional space in modern house guarantees the acute availability of spaces. This is to fulfill the space requirements of present residential trend of accommodating five bedrooms. The modern house plan exposed that formal areas of the drawing room and dining room along with powder room were placed in the first section of modern house areas planning. This was followed by semiformal area of living room and finally, the plan ended into private section like bedrooms. This approach is missing in traditional house with courtyard. Over the time, with the influence of globalization, these priorities have now become standards in house design. The striking feature in modern day house is the provision of powder room which is toilet area for guests. Efficient use of indoor space has been ensured by putting guest toilet under the landing of staircase. Also, it indicates of restricted movement of strangers and visitors in the house (Fig. 5.B).

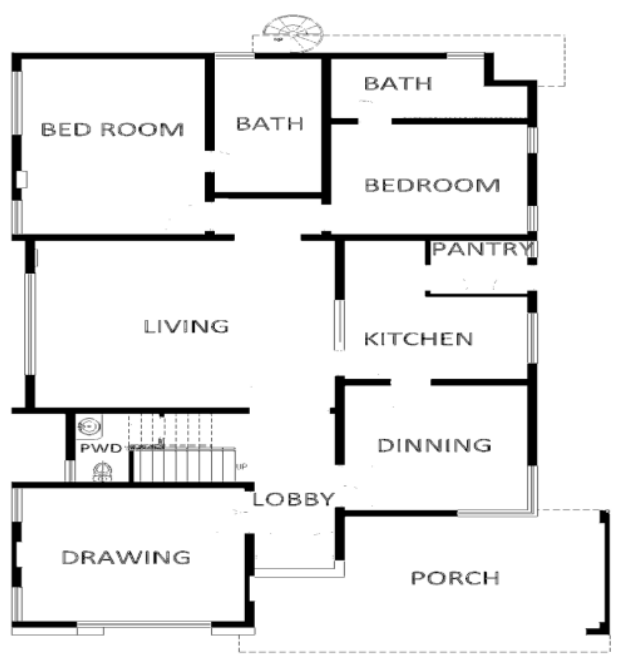

Fig.5B: Modern House Floor Plan

In the case of a traditional house, horizontal expansion is a salient feature as the density of public houses was low in the first few years after independence. Vertical expansion is now a common practice in house construction as residential land is getting more expensive due to rapid urbanization. The first floor has now become a compulsory component of modern housing in Lahore. Servant quarters were accommodated in first floor of modern house in contrast to the old location in a traditional house on the ground floor adjacent to the courtyard (Fig. 5.C).

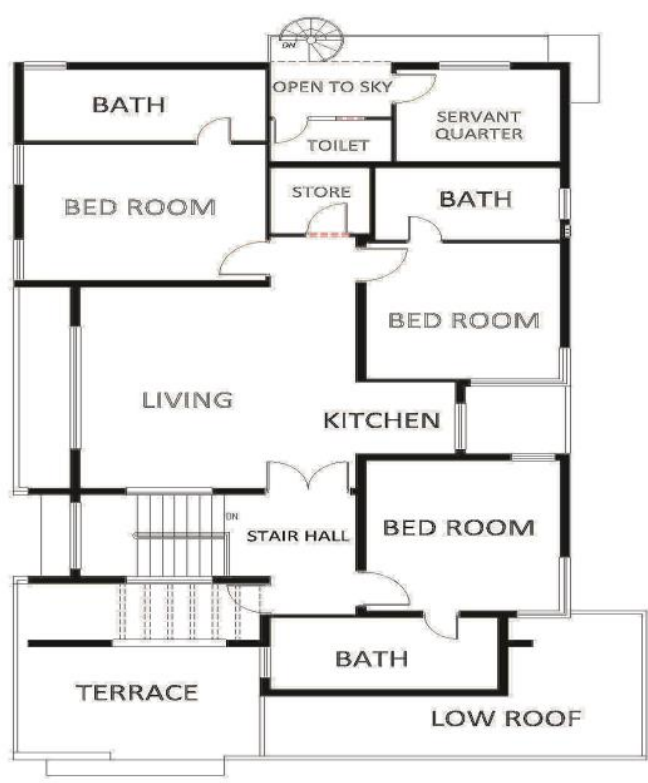

Fig.5C: Modern House First Floor Plan 


\subsection{QUALITY OF WALLS}

Brick masonry has been used as construction method for about a century and it still has maintained its reputation in new construction projects in many cities of Pakistan. The thickness of load bearing walls is generally considered to be 13.5 inches. Similarly, traditional house design also provides wall thickness of 13.5 inches thick walls for this reason. However, in modern day construction, brick masonry having walls of around 9 inches thickness, was found for a light-weight roof. Thinner brick walls and lower ceiling heights as modern construction practices are, then maintained through innovative ways of mechanical heating and cooling to survive the extreme hot and cold seasons.

\subsection{STAIRCASE DESIGN}

The staircase is a main element in house design as it is a source of vertical movement between the ground floor and first floor. Also, it is considered to be a transition point in architectural planning and design of any building type. In the case of a traditional house, the staircase was found as part of the courtyard leading to roof-top. The ultimate look of a staircase was unrefined with a simple paint finish (upper, Fig. 6). On the other hand, a staircase was placed as fragment of internal planning for modern house, satisfying the present concerns of comfort and security. In addition to this, this placement of staircase provides an easy source access to the upper story and rooftop in case of extreme weather conditions. A lavish finished look is blended with a stylish handrail made of polished wood and glass as a decorative feature for modern staircase. Lush black marble in polished form is used as a finish for the steps (lower, Fig. 6).
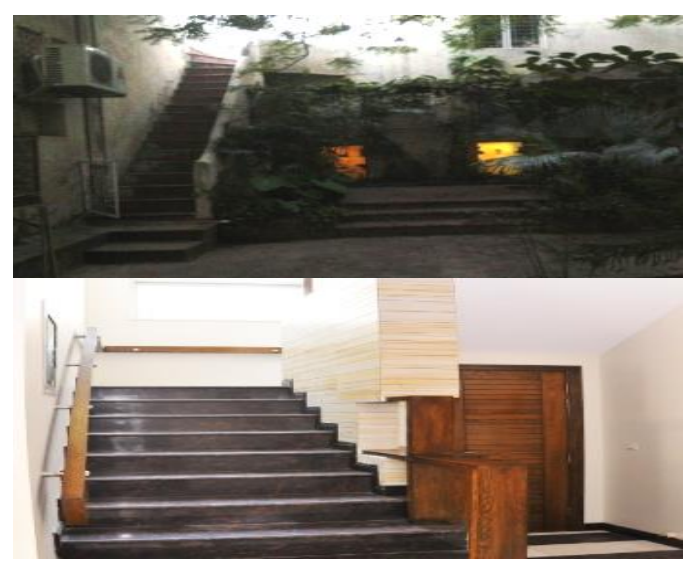

Fig.6.Traditional (Upper) and Modern Staircases (Lower), Source: Author
Natural lighting and ventilation are meant to be an integral part of traditional houses through the inner courtyard. It has proven to be an efficient source of directing natural breezes and sunlight into surrounding rooms and corridors. Another understanding behind, is to manage the extreme nature of weather in the Lahore region. This connects to the antique practice of naturally operated methods of heating and cooling by preceding generations. In present case of traditional house, the passageway was well-lit during the daytime due to secondary transparent door of wire gauze, in addition to main entrance door of solid wood, acting as a source of light and ventilation (upper, Fig. 7). Heights of traditional ceilings were observed to be high with a ventilator at the top level to assist in dispersing warm air. It maintains cooler environment inside the house (lower, Fig. 7).

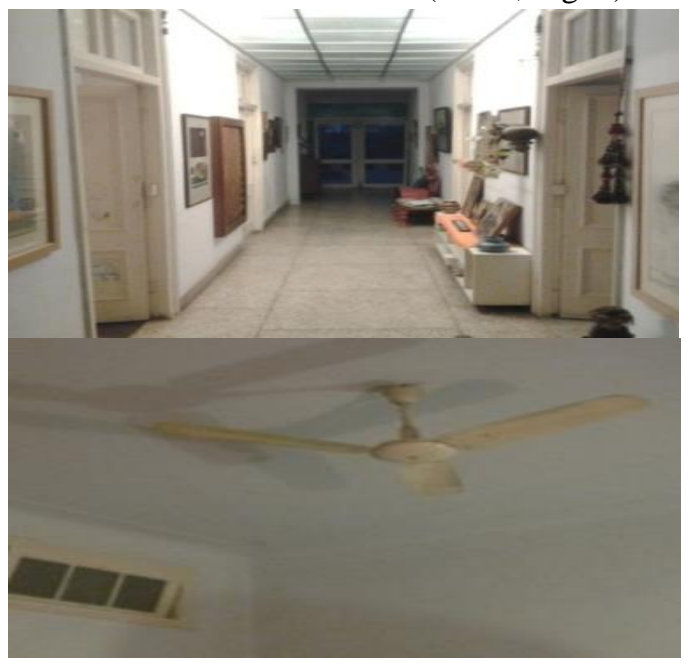

Fig. 7. Entrance Passageway of Traditional House (upper) and Traditional Ventilator (lower), Source: Author

Nowadays, people want to have more privacy; this attitude has caused a shift in lifestyle from outdoor to indoor spaces. This paradigm has reduced dependence on natural light. In a modern house, artificial lighting is a major focus of interior design. Quality of indoor space is maintained through chandeliers and false lighting on the wall in an artificial manner. Furthermore, usage of curtains on windows has also restricted cross ventilation (Fig. 8). An air conditioner was mounted on the wall of a lounge to maintain a cooler environment inside. No doubt, all these small details of architectural design truly play an important role in shaping patterns of our daily lives. 


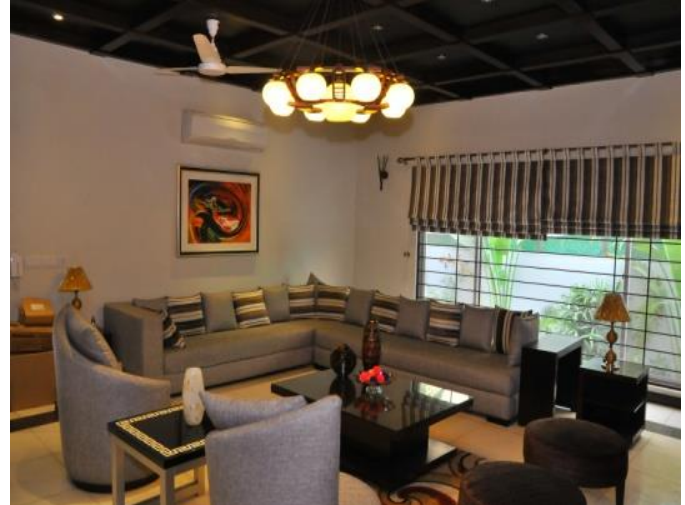

Fig. 8. Modern Living room, Source: Author

\subsection{DOORS AND WINDOWS}

The doors and windows are the key apertures in the building envelope and hold great potential from an architectural design point of view. The door and window designs provide a room of creativity. The fenestration of a traditional house was proposed in a decorative and ornamental manner (upper left, fig. 9). The hinged apertures (doors and windows) made of two wooden frames, embrace casing of both wire gauze and glass separately in the same place. This double set of frames enables the dual opening scheme towards both indoor and outdoor (upper right, Fig. 9). The doors and windows are relatively less decorated in the case of a modern house.
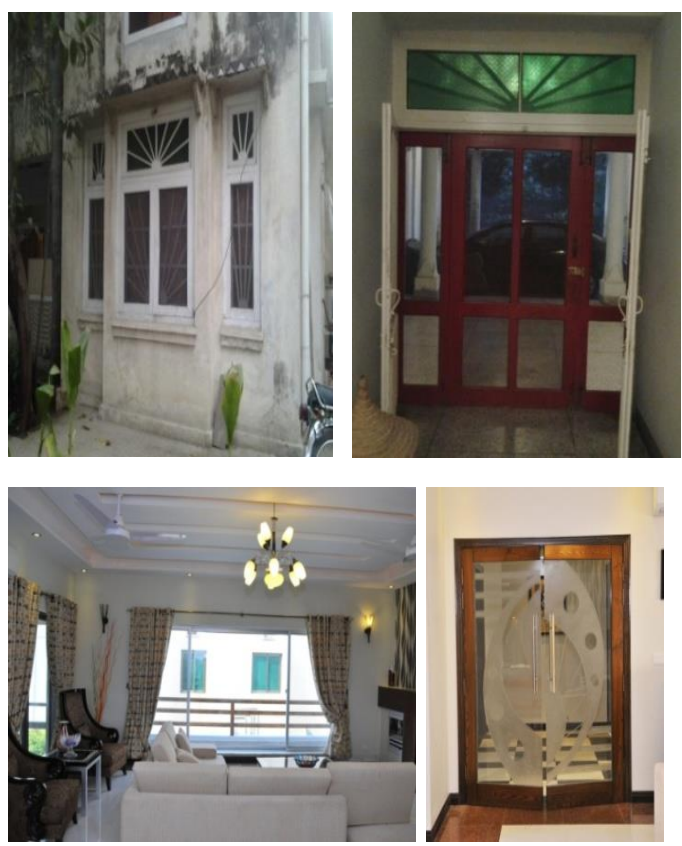

Fig. 9. Traditional Window (Upper Left), Traditional Door (Upper Right), Modern Window (Lower Left) and Modern Door (Lower Right), Source: Author
Contrary to a traditional window, there was one single aluminum frame with embedded glass installed, for a modern type of window (lower left, Fig. 9). Based on function and location of the window in the house, it can be either open or fixed. Presently, sliding windows are more fashionable than conventional windows with hinges. The door design incorporates latest materials with decorative features of glass-paper patterns. Modern door composed of polished wood and glass, was single framed with a stainless steel handle (lower right, Fig. 9).

\subsection{FAÇADE DESIGN}

The exterior look of traditional houses is usually characterized by architectural detailing and ornamental features. The traditional house of post-independence period exemplified the architecture with controlled ornamentation and detailing. Neglected maintenance of the exterior facade has left house with a crude look. Paint finish was applied as conventional material. A humble depiction of Doric columns was accompanied with screen patterns on the upper frame of the front face of the façade. The ornamentation consists of limited detail of overhangs and window frames (upper, Fig. 10)
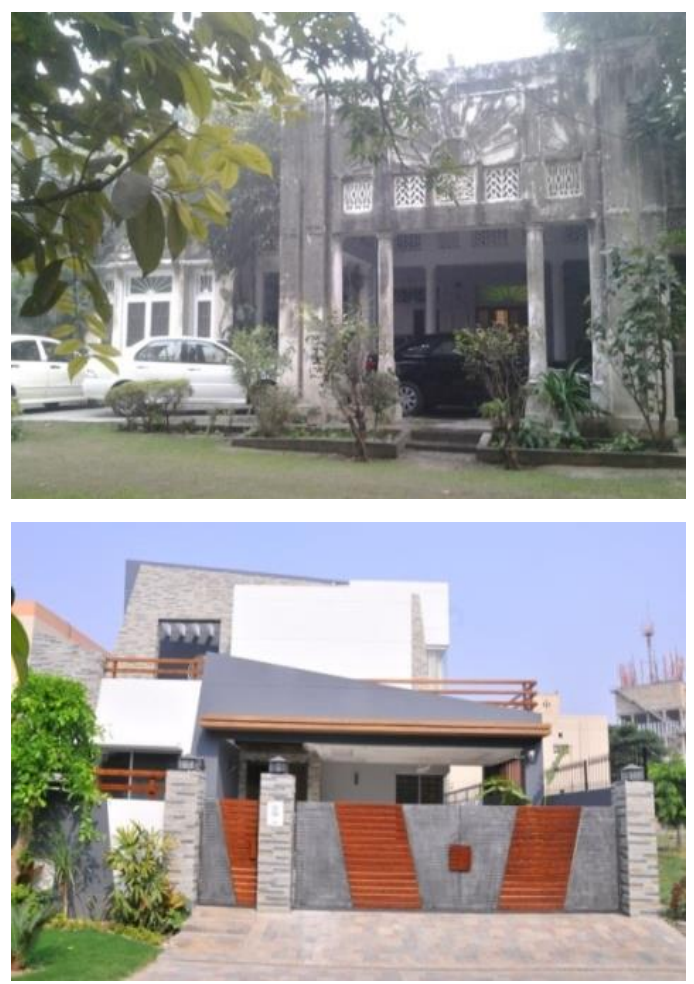

Fig. 10. Facade of Traditional House (Upper) and .Facade of Modern House (Lower), Source: Author 
The front elevation of the house is a parameter for prediction of architectural style. Exposure to the international market of architecture and the need for speedy construction has attracted architects and designers to a modern architectural style. The play of volumes through projection and depression of straight and diagonal forms are now trendy choices for house elevations. Such design patterns are easy to construct quickly compared to ornamental and detailed designs. Therefore, modern house elevation was recognized perhaps as an example of globalization with the application of the latest industrial exterior materials used for the front façade of a modern house (lower, Fig. 10).

\subsection{MISCELLANEOUS FEATURES}

A variety of prominent features of architecture and interior design can be discussed for both traditional and modern houses. Traditionally, the ceiling was featured with slight ornamentation at the fan point, establishing a focal point in the overhead plane (Fig. 11.A). The concept of 'angeethi' (traditional fire place) was fixed as conventional means of keeping space warm inside the living room. Here, angeethi had projected mass with minor detailing on the top, finished with a combination of plain and patterned tile in the lounge area (Fig. 11.B). In modern house design, the architectural features inside the house fall within the category of interior design under current trends of residential industry. Important design elements included false ceilings, wall treatments, and fire-places. Abstract patterns embedded with modern industrial finishes, emphasized through diffused artificial lighting, give a lively feeling to a dead wall (Fig. 11.C). A modern fireplace had a sleek finish of black granite and created a contrast to the back wall (Fig. 11.D).

(A) Ceiling Feature

(B) Angeethi
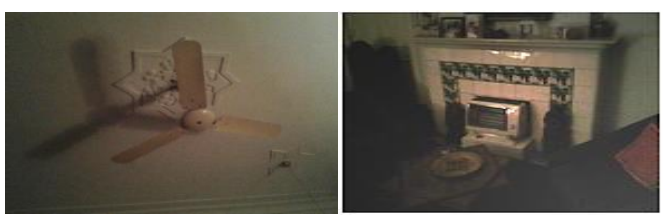

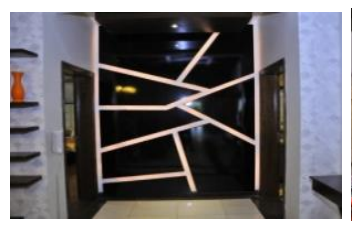

(C) Wall Treatment

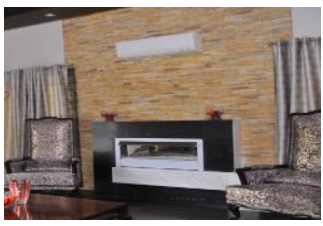

(D) Modern Fire-place
Fig. 11. Design Features of Traditional and Modern Houses of Lahore, Source: Author

\section{CONCLUSIONS}

The expression of individual and cultural identity in house design reflects the architectural value of the past, present and the future. However, traditional houses are considered to be more popular as the prototypes of environmental and cultural heritage of Lahore. Transformation of residential architecture was analyzed, based on the typological investigation of two types, traditional and modern. The changes were observed in every section of architectural planning and house designing. Open spaces were incorporated with enclosed areas in traditional houses. On the contrary, privacy and comfort were the focuses for modern houses. Ratio of covered area in a plot was relatively less in a traditional house when compared to the modern one. Space planning was compact for a modern house with efficient use of dead space. Brick walls were thicker for a traditional house. A prominent change had been observed for the location of a staircase from outside (traditional) to inside (modern).

A traditional house was more environmentally friendly than modern one. Doors and windows were more decorative in the past. Slight ornamentation on a traditional facade was observed versus modern elevation. This study attained further insights into spatial planning and architectural designing of houses in Lahore for traditional and modern categories. To ensure the permanence of traditional features in house designs, there is a need to nourish the soul of residential architecture by incorporating traditionalism with modernism. In this regard, prominent traditional characteristics including courtyards, thick brick walls, high ceilings, and verandas can harmoniously blend with the latest construction trends for accomplishing a balanced kind of house design in Lahore.

\section{ACKNOWLEDGEMENTS}

This study was supported by D Studio (architectural design consultants) in Lahore, Pakistan. The documented case study of modern house is a design project of D Studio. The architectural drawings generously provided by the team.

\section{REFERENCES}

Batool, A. (2014). Quantifying environmental performance of Jali screen facades for contemporary buildings in Lahore, Pakistan (Doctoral dissertation, University of Oregon). 
Bhardwaj, M., \& Garg, P. (2016). The bungalow-part of India's vernacular heritage. International Journal of Environmental Studies, 73(4), 604-615.

Burgess, C. S. (2005). Architecture, Town Planning and Community: Selected Writings and Public Talks by Cecil Burgess, 1909-1946. University of Alberta.

Chauhan, K., et al (2009). 'Housing Conditions in India: Problems, Policies and Perspective': V. Gandotra et al., 'Changing Housing Needs and Directions. Authors press, Delhi.

Lahore Development Authority. (2017, 05 13). Complete Building Regulations. Retrieved 03 06, 2019, from https://www.lda.gop.pk/docs/Complete\%20 Building\%20Regulations_LDA.pdf

Lodi, S.H., Sangi, A. J., \& Abdullah, A. (2013). Brick Masonry Construction In Pakistan: World Housing Encyclopedia. Oakland

Mubin, S., Gilani, I. A., \& Hasan, W. (2013). Mughal gardens in the city of Lahore-A case study of Shalimar Garden. Pakistan Journal of Science, 65(4), 511.

Nevile, P. (2006). Lahore: A sentimental journey. Penguin Books India.

Noble, W. (1987). Houses with Centered Courtyards in Kerala and Elsewhere in India. Dimensions of Social Life: Essays in Honor of David G. Mandelbaum, 48, 215.

Ovais, H. (2016). Architectural styles during the British Raj in Lahore. International Journal of Environmental Studies, 73(4), 616-630.

Qadeer, M. A. (1983). Urban development in the Third World: internal dynamics of Lahore, Pakistan. Praeger Publishers.

Qureshi, R. A. (2015). The traditional courtyard house of Lahore: an analysis with respect to Deep Beauty and sustainability (Doctoral dissertation, Kansas State University).

Rahmaan, A., \& Anis, B. (2009). Dynamics of Gated Communities, Their impact and Challenges for Sustainable Development: A Case Study of Lahore, Pakistan. ArchnetIJAR, International Journal of Architectural Research, 3(1), 57-70

Rana, I. A., \& Bhatti, S. S. (2018). Lahore, Pakistan-Urbanization challenges and opportunities. Cities, 72, 348-355.

Sengupta, R. (2007). Delhi Metropolitan: the making of an unlikely city. Penguin Books India.

Shafique, M., \& Shahid, A. R. (2016). Lahore in Pre-Colonial British Intellectual Space (1799-1849). Pakistan Journal of Social Sciences (PJSS), 36(1).

Vandal, P. (2009). 'Historiography of Architecture of Pakistan and the Region'.
Archi Times. Retrieved 04 08, 2016 from http://archpresspk.com/new-

version/Historiography-Architecture.html 